Jan Zawadka

\title{
1.6. AGRITOURISM IN MULTIFUNCTIONAL DEVELOPMENT OF RURAL AREAS
}

\begin{abstract}
Summary
After the change of the political system and the transformation of the economy, which depended on abandoning the planned economy, in Poland emerged features that shown agriculture and rural areas maladjustment to the new state model and a market economy that was being implemented. By the end of the 1980s, the main features of agriculture and rural areas were resulting from development model realised over the years, whose main objective was the agricultural production. The new reality disclosed low economic efficiency of many farms and the necessity to reorient the concept of developing regions with monofunctional agricultural character to the concept of differentiating their economies. A key problem connected with ensuring rural population improvement of the standard of living is developing non-agricultural functions in rural areas. The generally unprofitable agricultural production must be supplemented, or even replaced by other non-agricultural functions, e.g. tourism, handicrafts or agri-food processing. The article presents the issue of multifunctional development of rural areas and agriculture in Poland. One of the elements of this development is tourism in rural areas, and the related agritourism, which is treated as an important branch of the non-agricultural activities, not only on a local, but also on a national scale. The paper shows the most important economic and non-economic benefits associated with the development of agritourism, as well as the threats arising from it for the rural areas.
\end{abstract}

Keywords: agritourism, non-agricultural functions, rural areas, multifunctional development

\section{Introduction}

After the change of the political and economy system, in polish agriculture emerged features that showed its maladjustment to the new state model and market economy. Main features of farming and rural areas were the result of realised over the years development model, which fundamental goal was agricultural production. That is why the conception of regions with monofunctional character development states differentiating their economy, and a key issue concerned with providing local people better living standards is developing non-agricultural functions for rural areas. Unprofitable agricultural production must be supplemented and sometimes even substituted with other non-agricultural functions, e.g. tourism, craft, agri-food processing (Kłodziński and Rzeczkowska, 2000).

Development of rural areas is understood as a process of improving the economic situation and living conditions of people residing in these areas, which should be accompanied by an increase in the range and quality of the goods (including public goods) delivered from rural areas to whole society. Development integrity of these areas depends on harmonious combination of elements such as: economic growth (including creation of new workplaces and increase in real incomes of the population), 
preserving the natural habitat, improving living conditions in villages, protecting and enhancing cultural heritage (Wilkin, 1999).

\section{The essence and meaning of multifunctional development}

Since the beginning of 1990s, multifunctional development of rural areas has become the subject of not only state politics, but also subject of research. Already in the nineties in Poland came out many publications touching upon issue of multifunctional development. This development depends mainly on differentiating rural economy, thus withdrawal from monofunctionality generally relying on manufacturing raw materials. Integrating into rural economic space increasingly higher number of new and non-agricultural functions (Kłodziński, 1997), contributes to diversification of rural economy and abandoning farming as a one and only dominating function in rural areas (Zawadka, 2010).

Model of multifunctional rural areas development is acknowledged as one of basic categories of policy towards farming and rural areas in Poland, and its main purpose is (Kłodziński, 1999):

- living and working conditions improvement of families living in villages,

- equalization of their living standards against the city dwellers standards,

- increasing of non-agricultural employment,

- greater possibilities in choosing work and its diversity.

All of this should contribute to the improvement of rural population incomes and increase the attractiveness of the countryside as a place for living and working, in consequence, leading to its socio-economic development.

Multifunctional development of rural areas may be considered on two levels - the socio-economic and spatial. The first aspect concerns the rational use of production factors available to the village, while the second refers to the proper distribution of man's socio-economic activities in economic space and results from the process of planning and area spatial management (Hopfer et al., 2000).

The idea of multifunctional development is the way to solve many problems of agriculture and rural areas, and the implementation of this model is based primarily on the creation of new, various sources of revenues for non-agricultural and agricultural population, who is not able to find a full employment in their own farms. New workplaces should be created, according to Kłodziński, namely in the rural technical and commerce service field, agri-food industry, near the investments related to infrastructure development, environmental protection, development of tourism, craft and industry. Special departments in agriculture may also become a source of new incomes. Growth of rural families' income can be stimulated by intensification of agricultural management, off-farm contract work and also non-agricultural use of farm resources. Multifunctionality therefore is reduced to a practical mode of action done through the multiple way utilization of owned potential (Kłodziński, 1995).

Rosner (1997) considers multifunction as a response to the necessity of increasing the number of workplaces in local systems, in which agriculture plays a dominant role, despite the fact that demand for work in this sector is decreasing. The meaning of the 
concept, therefore, is reduced to an increase in diversity of employment fields, and a growth in variety of the rural population source of upkeep in local systems.

Above listed approaches to the problem of rural areas multifunctionality were primarily focused on the issue of the rural economy diversification. But this is not a sufficient interpretation range of the analysed category. As pointed out by Kłodziński, the concept of multifunctionality cannot be identified solely with the process of creating new workplaces. This is a much broader concept, related to local development, entrepreneurship, strategic planning, diversification of agriculture, infrastructure development, improvement of demographic resources, etc. (Kłodziński, 1996)

It should be emphasized that beyond functions of an economic nature, more and more recognised and appreciated are social functions performed by rural areas. The basic activities realised in rural areas, such as agriculture and forestry, fulfil important natural and cultural functions (Banski and Stola, 2002).

Understanding the multifunctionality of rural areas wider than as the socioeconomic activities and taking into account their natural and cultural functions is consistent with the principle of sustainable development, understood as achieving simultaneous progress in three areas, i.e. economic, social and environmental. However, this is largely dependent on the course of economic functions development process.

A similar standpoint is represented by the Organization for Economic Co-operation and Development (OECD), which denominated two levels of multifunctionality interpretation (OECD, 2001). The first is the analysis of the multifunctionality as a property of economic activity, about which attest various, combined products or the effects of activity (e.g. positive or negative, intended or unintended). Some of them have a market value, others are excluded from the operation of the market mechanism. Multifunctionality is therefore a feature of many types of economic activity and it does not refer exclusively to agriculture. The second way of the multifunctionality interpretation regards assigning different roles to agriculture. From this point of view, farming as an economic activity has been entrusted to perform certain functions in society. As a result, beneath the concept of multifunctionality lies not only a feature of the production process, but also some values (functions) important for the whole society are contained. A juxtaposition of market and non-market functions of agriculture is presented in Table 1.

Importance of multifunctional development was also articulated in Agenda 2000, which is a set of reform proposals designed to modernise European Union policies and prepare it for expansion. It was remarked in this document that reforms concerning rural areas were expected to contribute to the creation of multifunctional and competitive agricultural sector, ensuring the future of weaker rural regions, and also to promote multi-directional agriculture in the context of rural development global strategy.

The necessity for multifunctional development of rural areas is emphasised in a number of polish planning documents concerning rural areas and agriculture. It constitutes the basis for the implementation of Poland's National Strategic Plan 20072013 (Program Rozwoju Obszarów Wiejskich 2007-2013, henceforth PROW) and 
consequently is an instrument of support for rural areas development in the framework of PROW 2007-2013. PROW assumes economic empowerment of farms and competitiveness increase in the agri-food sector, with simultaneous provision of instruments in favour of economic activities diversification in order to obtain and create alternative sources of income for rural population.

Table 1: Classification of market and non-market functions of agriculture

\begin{tabular}{|c|c|c|c|}
\hline Productional & Social & Cultural & Environmental \\
\hline $\begin{array}{l}\text { Commercial: } \\
\text { - food products } \\
\text { intended for the } \\
\text { market, } \\
\text { - farm products } \\
\text { comprising } \\
\text { industrial raw } \\
\text { materials, including } \\
\text { biomass. } \\
\text { Non-commercial: } \\
\text { - household self- } \\
\text { supplying with food, } \\
\text { - manufactured in the } \\
\text { farm } \\
\text { - capital goods for the } \\
\text { farm own needs. }\end{array}$ & $\begin{array}{l}\text { - influence } \\
\text { on village's } \\
\text { social } \\
\text { vivacity } \\
\text { and } \\
\text { cohesion }\end{array}$ & 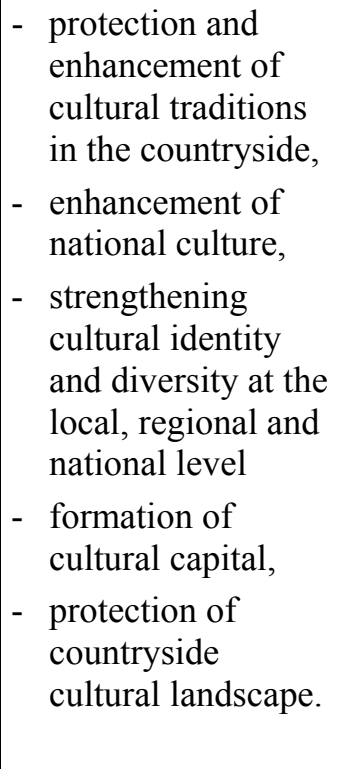 & $\begin{array}{l}\text { Negative: } \\
\text { - } \text { soil and water pollution with } \\
\text { chemicals, } \\
\text { - } \text { soil erosion, } \\
\text { - } \text { reduction of farmland } \\
\text { biodiversity, } \\
\text { - greenhouse gas emissions. } \\
\text { Positive: } \\
\text { - } \text { arable lands prevention from } \\
\text { natural degradation, } \\
\text { - protection of farmlands } \\
\text { biodiversity, } \\
\text { - protection or improvement } \\
\text { of water supplies on } \\
\text { farmlands, } \\
\text { - prevention of soil erosion. }\end{array}$ \\
\hline
\end{tabular}

Source: Wilkin (2007)

Multifunctional development of a village is therefore an important factor, at the same time aspect of the sustainable development process, but only in a situation when rural economic function development is not associated with negative consequences for its natural sphere (Adamowicz and Zwolinska-Ligaj, 2009). On the other hand, it should be noted that the source of rural non-agricultural functions development can be preserved, high-quality natural and landscape values which contribute to the possibility of extending tourism function in these areas.

\section{The benefits associated with the development of agritourism}

As was previously mentioned, one of the elements of rural areas multifunctional development is agritourism, which as an economic, social, cultural and spatial phenomenon, includes factors arousing local development. Economic and social consequences of agritourism development, as an alternative form to mass tourism, are correspondingly smaller, but provide opportunities for its harmonious inclusion into socio-economic life of the community. The most frequently mentioned features and benefits associated with the development of agritourism are those with an economic character. As the most important among them the following can be identified: 


\section{Agritourism farm owners and other village inhabitants' additional income}

Incomes derived from tourists presence are possible not only from renting rooms, but also from: selling them our own products, meals, handicraft, hiring sports equipment, teaching horse-riding, providing rehabilitation services and many more. Due to the presence of tourists in the borough also its dwellers have benefits financially. These benefits are results running a shop or bar, selling handicrafts, organizing sleigh and carriage rides, and renting horses for horse-riding and horseback riding lessons.

At this point it should be mentioned about the so-called multiplier effect (see Milne, 1990; McIntosh and Goeldner, 1990; Majewski, 2004), stimulating local economic situation. Arrival of tourists triggers increased demand for other products and services, which may not have anything in common with tourism. Therefore, in many countries, much store is set by the development of tourism as a field allowing for an economy revival in a relatively short period of time.

In the boroughs having relevant climatic and natural amenities additional revenues come from local taxes paid by its visitors.

\section{Fostering economic initiatives and the creation of new workplaces}

Arrivals of tourists to agritourism farms and profits of farm owners may be a source of inspiration for many rural residents to start receiving guests in their own farm or providing additional services for visitors, which will diversify their stay and rest. The essence of entrepreneurship in a market economy is searching for new fields of activity or creative imitation of the existing ones (Sikora, 2002). Depending on the local natural and cultural values, as well as the resources of their own farms, active citizens wishing to take advantage of the presence of tourists often decide on the provision of food, recreation, sports or cultural services, as well as manufacturing and selling traditional food and souvenirs (Tyran, 2005).

It is estimated that one farmstay makes about 10 new jobs (Debniewska and Tkaczuk, 1997) in a rural area, and creating one new workplace in tourism - including agritourism - requires only $40 \%$ of expenditures needed to create such a place in the manufacturing industry (Kmita, 1997).

The hosts' activity is very important here, because they are originators of recurring events for tourists and residents, they effectively acquire sponsors, are the founders of local tourist organizations and the seasonal tourist information centres establish associations, activate local government, etc. Manifestation of these people spirit of enterprise is also necessary for their own business to develop and get better, which requires continuous investment in the properties and enforces the extension of the offer and improvement of the services quality.

\section{Reducing unemployment, employment growth}

A common problem of the Polish countryside is a high unemployment rate and labour surplus in agriculture. The complex nature of rural tourism projects needs a wide range of associated services positively influencing the creation of new 
workplaces in branches indirectly related to tourism services, which to a large extent may have an effect in the mitigation of the above mentioned problem. What is more, the chance of finding an employment in a place of residence is an inhibitor to migration of young people who cannot see their prospects in the countryside.

The development of agritourism is an occasion to reconstruct many vanishing professions, since tourists have a great interest in rural handicraft. This is a chance especially for elderly people who are familiar with the profession of a smith, an embroidery woman and wickerwork manufacturer, or folk art pottery, which creations have already been undervalued and are often forgotten by the local community, but still can find buyers among the visitors. Great potential in this area lies also in the traditional local food that is very popular and appreciated by tourists.

\section{Activation and ennoblement of rural women}

The activation of rural women is a particular benefit of agritourism development (Sawicka, 2005 and 2008). Since, the vast majority of preparing for an attractive offer (room, bed linen, trinkets in the room, laying the table, toilet, attractive cuisine, most of the accompanying services, etc.) is the domain of women. It is so important for rural areas, because when the general difficulties of finding a job occur, it is much harder to find a work for women than for men. Thanks to activity, which agritourism is, a number of rural women for the first time in their life have a chance to enter the job market and get their first income.

Leading an agritourism activity and providing a wide range of services within its framework gives the possibility to use the intellectual potential and skills of rural women. They willingly participate in various trainings, exchange their experiences, cooperate in the clubs of country housewives, compete in competitions (e.g., in cooking or for the best and most beautiful agritourism farmstead), sell own made handicrafts and own prepared meals. Moreover, the fact that many of them act agritourism associations governors or village representatives in their villages causes ennoblement of the women social position in the local community.

\section{Local infrastructure improvements}

The increase of aesthetics, quality, creation of new technical infrastructure and improvement of the existing one are the essential actions of local government and entities interested in developing tourism, undertaken in order to create a positive image of the town, indispensable in effective development of this and also other forms of tourism. The same applies to projects undertaken at the level of individual farms where large part of the capital and funds obtained from the EU is allocated for various investments, inter alia: renovation, modernization and expansion of buildings, transformation of farm buildings and improving the aesthetics of the farm surroundings.

Investments, undertaken by boroughs, focused on development and modernization of the local technical infrastructure, which contributes to improving the quality of services for tourists, concern: local roads, parking lots, sidewalks, street lighting; waterworks and sewerage system, local sewage treatment plants; landfills, separate 
waste collection, etc. A notable number of farmstay tourists prefer spending their leisure time active. Hence the necessity of creation or modernization of a local recreational facilities, examples of which inter alia are: playgrounds for various team sports, ice rinks, developing slopes for skiing, bicycle paths, bridle paths, footpaths, water routes and harbours, beaches, marking of tourist trails, tourist information points.

Above listed investments in tourism infrastructure not only considerably determine the possibility of extending the tourist function in the area, but also conduce to the creation of new workplaces and influence life quality enhancement for all residents.

\section{Transfer of capital from the cities to the countryside}

Each tourist in the place of his temporary stay leaves some money. In the case of agritourism these people are mostly city dwellers who usually when coming to the farmhouse do not restrict themselves to use only its offer (Alejziak, 2001). Such holidaymakers often actively participate in many aspects of rural life and dispose their budget freely. The transfer of money from a city to a village regards vast majority of the local economy elements, ranging from gas stations to the confectionery with regional delicacies.

A great number of tourists are people interested in active recreation, so part of their expenditure is connected with experiencing different kinds of emotions and the acquisition of sports and leisure skills. Hence, sometimes a large sum of money expended by tourists goes to i.a. those who provide horses for horseback riding, organize carriage and sleigh rides, deal with bicycle, water sports equipment and quad rentals. Also climbing walls and extreme sports such as paragliding are becoming more and more popular. Entertainment like this is expensive, which intensifies the discussed phenomenon. Often omitted in many studies, however, worth noticing is the fact that the influx of tourists also reflects positively on the funds of rural parishes.

Agritourism is mainly seen through the prism of economic benefits achieved by hosts and the local community, and also the prosperity of the local economy. However, the development of this form of tourism is also associated with less important noneconomic nature benefits. The most important are:

\section{Ennoblement of rural residents and their lifestyle}

Thanks to the arrival of citizens to agricultural farms deeper understanding of two different communities (urban and rural) is possible. Tourists, who pleasantly and efficiently spent their free time in rural environment, made closer relationships with their hosts and other members of rural society (which often become long-term acquaintances and friendships) change their, not always positive, vision of rural residents. Having a rest at such a farm provides an opportunity for: gaining or expanding knowledge about agricultural practices, getting to know and taking part in production processes, learning about problems of animal husbandry and other issues related to the foodstuffs manufacturing.

Staying at a farmland is also a great occasion to meet folk culture and learn about still cultivated rural customs and traditions which are often different from those of 
urban residents, and to taste the local food and drinks. Such experiences are reflected in growth of understanding and respect for visited rural communities. They may become a basis for interpenetration and integration of different cultures.

\section{Increasing level of qualifications}

A farm owner should be characterised by courtesy, benevolence, patience and easiness in establishing new relationships. Such a person should maintain managerial skills and prescience. Character features are very important assets of the host. However, it needs to be emphasised that efficient development of agritourism ventures should be accompanied by not only investments made in farm, but also in human resources. On becoming more and more competitive agritourism market it is essential to systematically update knowledge and take part in trainings concerning tourism issues, which will allow making offer more attractive and improve the quality of the provided services (Jalinik, 2010). Tourists influence should also be stressed, because for the hosts they are a source of information and knowledge about different disciplines. Contact with people from cities very often has positive effect on rural youth aspirations and life plans - stimulated by visitors example and career accomplishments young people set more ambitious goals. Whereas, presence of foreign tourists reflects in motivation to learn foreign languages and acquired contacts may facilitate journeys abroad.

\section{Activation of rural community, strengthening of social bonds}

A considerable part of residents, living in regions where agritourism is being developed, is characterised by great activeness in self-organisation and ability to cooperate. An evidence of this fact is at least presence of numerous agritourism associations and local tourist organisations. Its members act in favour of region's promotion, agritourism development and other tourism forms. They demonstrate their activeness in acquiring and taking advantage of funds (also those coming from European Union) for variety of ventures which will make this development faster and easier. Hosts aware of the benefits associated with tourist stay, who aim at attracting greater number of tourist, strive for an increase in quality of services they provide and its diversification. That is why, many times they undertake cooperation with other owners of agritourism farms, disposers of gastronomic infrastructure and diverse tourist attractions, and also the rest of rural residents who may contribute to enrichment of the offer and making it more attractive. It should be underlined that both agritourism development and widely understood local development is possible thanks to realisation of cooperation principles, when responsibility for the place of residence is felt by all the members of community.

\section{Protection of cultural values}

Rural residents' cultural activity is extremely important for tourism development. Tourists' presence gives an argument for folk bands to work, local culture and religious traditions to be supported, organisation of feasts, church fairs, harvest festivals and other common amusements uniting local population and visitors. Tourist 
interest in regional attractions also allows rural residents to look at their surroundings from other perspective and value it. Thanks to tourism influence increases tolerance for distinctness of behaviours and differences in customs.

\section{Protection of valuable natural areas}

Agritourism development, which one of the greatest trump is contact with nonpolluted environment and its resources (Klisinski, 2005), sometimes causes anxiety of the future of natural values located in polish villages. However, agritourism realised in accordance with conception of sustainable development may occur to be a form of valuable terrains protection, which also does not exclude their simultaneous economical utilisation (Wiatrak, 2005).

Agritourism contributes to creation of so called "green workplaces", integrating development of tourism and principles of environmental protection, which is conducive to sustainable development of rural areas.

A way of natural value areas protection against degradation and pollution caused by tourism exploitation is to increase an ecological consciousness of local governments, communities and people who should be the most interested in preserving natural habitat values, that is tourists.

It is impossible to predict all the benefits which may arise from starting an agritourism business. Many of them have incommensurable character or do not reveal oneself in material form, but simply embodies in better living conditions.

Agritourism will bring that the local economy gets multifaceted, becoming less susceptible to market unsteadiness, which is important in typically agricultural areas. Thanks to tourism business farm families acquire new skills and learn entrepreneurship, which can pay off in other disciplines. Mere contact with visitors and exchange of views bring immeasurable, but significant benefits. For example, in case of foreign visitors tourism mobilises foreign languages learning (Majewski, 2004).

However, it should be noted that in a number of benefits associated with the development of agritourism may also occur risks and negative consequences. Agritourism, as well as other forms of rural tourism may become a threat to the environment, especially in case of over-concentration of tourist attendance.

Practicing various forms of active recreation, such as: downhill skiing, horseback riding, rock climbing, bike racing and hiking expeditions can cause degradation of the rural landscape, pollution and excessive noise. Just as an excessive number of tourists may harm the natural environment, so their stay in the rural areas can destabilise the local socio-cultural environment and disrupt the rhythm of rural life and work, and also raise conflicts between tourists and residents due to transferring of urban lifestyle and a different system of values to the village (Jędrzejczyk, 1995).

Agritourism can also cause irreversible changes in the rural area through its accompanying intense urbanization processes (Strzembicki, 1997). Uncontrolled infrastructure development often destroys a traditional architectural layout of the place. A village sometimes loses its identity its unique colour and special atmosphere. Tourist destinations offer more commercialised and often counterfeited version of its customs and folklore, tailored to the tourists' expectations and imagination (Przecławski, 1986 and 1996). 
Regional culture becomes a culture for sale, losing its authenticity and value. Meaningful is also the fact that in many touristic places during the season the appreciation of price level occurs. This reflects adversely not only on tourists, but also on local people, especially ones who do not receive any benefits from the increase of tourism traffic. It happens as well that the land prices and prices of many services are rising (Różycki 2006).

However, it should be noted that the listed examples of threats to the natural and social environment of rural areas can be effectively prevented through skilful tourism management and obeying the principles of sustainable development.

\section{Conclusion}

Prerequisite for success in agritourism is inter alia the positive attitude of the main stakeholders towards tourism, i.e. the residents of the village. It is expressed primarily through hospitality. But only hospitality is not enough. Some appropriate skills of hosts are necessary and also adequately prepared local development plan is needed, which includes the development of tourism. Undertaking actions for the development of tourism requires carrying out a meticulous account of the benefits and risks.

Tourism, beyond the benefits of raising money and economic recovery, also requires long-term investment aggravating all the inhabitants of a certain village, so not only those who will directly benefit from the influx of tourists. Tourists will not come to the village which lacks basic infrastructure related to recreation and leisure. Room rental, guest services, organizing their leisure time often requires a significant financial investment, related not only to the renovation of the house, but also to equipping it so as to provide visitors the appropriate standard.

To increase revenues from tourism, municipalities and local communities should concern about the largest possible number of tourists visiting a particular place, simultaneously taking into account the tourist capacity. It is lucrative not only to extend the length of tourists stay, but also to extend the tourist season by introducing new functions independent of weather conditions.

Increased visitors expenditure can be achieved not only by raising prices, but also by the introducing variety of additional attractions, suitably managing the area. Often reservation arouses the fact of indifference or jealousy of the rural population which does not gain the financial benefits from tourists' presence. Meanwhile, all residents may get some profits from the development of tourism in the municipality.

Making the community and the authorities of territorial units aware of this fact and incorporating it during masterminding the municipality development strategy is an important factor in aiming at diversification of the municipality incomes and increasing revenues from tourism.

However, a particular attention should be paid to the fact that agritourism is only one of the elements of rural areas multifunctional development. Placing too much hope in agritourism is risky for the municipalities which are deprived of any tourist values. 
Researches concerning rural tourism market, including existing and potential customers, are therefore necessary.

Future of rural tourism depends largely on good orientation in groups of services in which tourists are interested and also in segmentation of tourists.

\section{References}

1. Adamowicz M., Zwolińska-Ligaj M. (2009): Koncepcja wielofunkcyjności jako element zrównoważonego rozwoju obszarów wiejskich. Polityki europejskie, finanse i marketing. Zeszyty Naukowe Szkoły Głównej Gospodarstwa Wiejskiego w Warszawie. Seria E no. 2 (51), vol. II, p. 17.

2. Agenda 2000.(1999): Umocnienie i rozszerzenie UE, p. 8.

3. Alejziak W. (2001): Turystyka w obliczu wyzwań XXI wieku.

4. Bański J., Stola W. (2002): Przemiany struktury przestrzennej i funkcjonalnej obszarów wiejskich w Polsce. „Studia Obszarów Wiejskich” vol. 3, pp. 15-16.

5. Dębniewska M., Tkaczuk M. (1997): Agroturystyka - koszty, ceny, efekty, p. 12.

6. Działanie w zakresie agroturystyki i turystyki wiejskiej. Opracowanie Ministerstwa Rolnictwa i Rozwoju Wsi, 2000.

7. Hopfer A., Bajerowski T., Suchta J. (2000): Możliwości wielofunkcyjnego rozwoju obszarów wiejskich północno-wschodniej Polski na przykładzie Warmii i Mazur. (in:) Możliwości wielofunkcyjnego rozwoju wsi polskiej w kontekście integracji z Unią Europejską. Aspekty regionalne, p. 219.

8. Jalinik M. (2010): Agroturystyka na obszarach przyrodniczo cennych.

9. Jędrzejczyk I. (1995): Ekologiczne funkcje i uwarunkowania turystyki, p. 65.

10. Klisiński J. (2005): Agroturystyka alternatywą, In: Agroturystyka jako element rozwoju i promocji regionu, Ed. E. Gurgul.

11. Kłodziński M. (1995): Rozwój rolnictwa w powiązaniu z wielofunkcyjnością terenów wiejskich. (in:) Rolnictwo w gospodarce Opolszczyzny. Znaczenie, perspektywy, zagrożenia, pp. 22-23.

12. Kłodziński M. (1996): Wielofunkcyjny rozwój terenów wiejskich w Polsce i w krajach Unii Europejskiej, p. 62.

13. Kłodziński M. (1997): Istota wielofunkcyjnego rozwoju terenów wiejskich. (in:) Ekonomiczne i społeczne uwarunkowania i możliwości wielofunkcyjnego rozwoju wsi w Polsce, p. 41.

14. Kłodziński M. (1999): Aktywizacja gospodarcza obszarów wiejskich, pp. 10-11.

15. Kłodziński M., Rzeczkowska M. (2000): Rozwój przedsiębiorczości wiejskiej w krajach Unii Europejskiej - wskazówki dla Polski, In: Rozwój przedsiębiorczości wiejskiej w warunkach integracji z Unią Europejską, p. 81.

16. Kmita E. (1997): Agroturystyka jako szansa aktywizacji społeczno-gospodarczej środowisk wiejskich. „Zagadnienia Doradztwa Rolniczego" nr 2, p. 11.

17. Kmita, E. (1997): Agroturystyka jako szansa aktywizacji społeczno-gospodarczej środowisk wiejskich. „Zagadnienia Doradztwa Rolniczego” 1997, nr 2.

18. Kożuchowska B. (2000): Podstawowe pojęcia, cechy, składniki agroturystyki oraz formy samoorganizacji usługodawców, In: Agroturystyka. Ed. U. Świetlikowska.

19. Krajowy Plan Strategiczny Rozwoju Obszarów Wiejskich na lata 2007-2013, p. 33, 2007.

20. Majewski J. (2004): Agroturystyka to też biznes.

21. McIntosh R.W., Goeldner Ch.R. (1990): Tourism Principles, Practices, Philosophies. 
22. Milne S. (1990): Tourism and Economic Development in Vanuatu. Signapore Journal of Tropical Geography No. 11.

23. OECD (2001): Multifunctionality: Towards an Analytical Framework. OECD, p. 14.

24. Program Rozwoju Obszarów Wiejskich na lata 2007-2013, pp. 121, 2007,

25. Przecławski K. (1986): Humanistyczne podstawy turystyki.

26. Przecławski K. (1996): Człowiek a turystyka. Zarys socjologii turystyki.

27. Rosner A. (1997): Demograficzne uwarunkowania wielofunkcyjnego rozwoju na obszarach wiejskich. (in:) Ekonomiczne i społeczne uwarunkowania i możliwości wielofunkcyjnego rozwoju wsi w Polsce, p. 137.

28. Różycki P. (2006): Zarys wiedzy o turystyce, p. 77.

29. Sawicka J. (2008): Sytuacja kobiet wiejskich na rynku pracy.

30. Sawicka J.: (2005): Rola kobiet w aktywizacji i wielofunkcyjnym rozwoju obszarów wiejskich.

31. Sikora J. (2002): Agroturystyka czynnikiem rozwoju gospodarki rynkowej na obszarach wiejskich. In: Socjologiczne i ekonomiczne zagadnienia gospodarki rynkowej - szanse i zagrożenia.

32. Strzembicki L. (1997): Uwarunkowania rozwoju agroturystyki i usług towarzyszących na obszarach wiejskich. (in:) Agroturystyka w społeczno-ekonomicznym rozwoju środowiska wiejskiego, p. 7, 1997.

33. Tyran E. (2005): Podstawy agroturystyki, In: Agroturystyka i usługi towarzyszące, Ed. W. Musiał, J. Kania, L. Leśniak.

34. Wiatrak A.P. (2005): Turystyka wiejska w strategiach rozwoju regionalnego i lokalnego, In: Turystyka wiejska a rozwój i współpraca regionów. Ed. Z. Kryński, E. Kmita-Dziasek.

35. Wilkin J. (1999): Pozarolnicze funkcje obszarów wiejskich. Roczniki Naukowe SERIA, vol. 1 , no. 3, p. 28.

36. Wilkin J. (2007): Wielofunkcyjność rolnictwa i obszarów wiejskich. (in:) Wyzwania przed obszarami wiejskimi i rolnictwem w perspektywie 2014-2020. Nowe Życie Gospodarcze, p. 4, November 2007, Special Appendix.

37. Zawadka J. (1990): Ekonomiczno-społeczne determinanty rozwoju agroturystyki na Lubelszczyźnie: (na przykładzie wybranych gmin wiejskich). 